were collected-but not described," for which I beg to apologize to Mr. W. T. Blanford.

Mr. W. T. Blanford's remark "that Cycads have not hitherto been found in the Damudas" was therefore in so far correct as the mentioned specimens, with the exception of Nöggerathia? Hislopi, althongh found have hitherto not been determined until I did so.

I should also, when writing in the September Number of the GroL. Mag. 1877, p. 431, that "Zamia Burdwanensis, McClell., has been described as long ago as 1850," have added that the affinities of this species had been later disputed for many years, Dr. Oldham supposing, from the material at his disposal, that a Schizoneura has been mistaken for a Zamia, until, through the recovery of the original specimen, this species was proved to be indeed a Zamia. (I described this species fully, with its history, in Reo. Geol. Surv. of India, 1877, vol. x. No. 2.)

I wrote in the November Number of the GeoL. Mag. 1876, already referred to: "From the occurrence of the genus Glossopteris in these beds (Danudas), they have been for a long time brought into oonnexion with the Australian Coal-measures, and declared without any proof as probably Palæozoic," and I referred to Dr. Oldham, Mr. H. T. Blanford, and Mr. W. T. Blanford as authorities. This was the impression left upon me after the perusal of the papers referred to-but 'I should have explained that besides Glossopteris, some other fossil plants also were mentioned as correlating fossils. I express my regret for having left these other correlations unconsidered, but I hope to be able to explain this point further in the Flora of the Lower Gondwanas in India. This note refers to all my publications on this subject. Otrokar Feistmantel.

CALCUTTA, Oct. 9, 1877.

\title{
PROFESSOR MILNe AND THE GLacial PHeNomena OF SCANDINAVIA.
}

SrR,-It is not without great astonishment that I-and, I think, most geologists who have devoted any attention to the post-Tertiary formations of Northern Europe-have read a paper by Professor John Milne in your last July Number. ${ }^{1}$. By some observations made from the railway waggon, or the steamer, when travelling through Sweden and Finland, he thinks himself enabled to refute the views since many years universally held by Scandinavian geologists respecting the surface geology of the country. The features usually attributed to the action of glaciers on a continental ice-sheet-as, for instance, the polished and scratched rocks and the boulders-he thinks better explained by the action of coast-ice. If Professor Milne had stayed a day in Sweden, and made an excursion with a Swedish geologist, I hardly doubt that the first part of his Travelling Notes would have been unwritten, for it seems impossible that a person with such good reasoning powers should hold the views advocated in those notes, after seeing a few of these scratched rocks

1 J. Milne: Across Europe and Asia. Travelling Notes. Part I. London to St. Petersburg. Grol. Maa. Dec. II. Vol. IV. p. 289 seq. 
and the associated phenomena near enough, and having their bearings pointed out to himself by an experienced guide. As they have now been written, and published in a Journal of such a standing as the Geologicas Magazin n, they ought not to be altogether unanswered, though $I$ think that most of your readers do not need to have the failings of such reasonings pointed out.

The chief argument of Professor Milne against the glaciation theory seems to be that that theory requires great climatal changes, the explanation of which would involve insuperable difficulties. I admit that Science has not yet given a final explanation of these changes, but they are a well-established fact, and a fact must be accepted, whether we can explain it or not. As for myself, I think that the physical features-such as the nature of the Till and the striation of the rocks-are in themselves sufficient proofs of a former glacial climate, but there are, besides, ample palæontological evidences. Some thirty years ago, Professor Lovén found that certain shell-banks in Southern Sweden contain a completely Arctic fauna, and the labours of the Geological Survey of Sweden have shown that the stratified clay reposing on the gravel-beds is every where characterized by the well-known shell Yoldia arctica, Gray, which ocenrs living only in the most Arctic regions, as the coasts of Spitzbergen and those of northern Greenland. Still more striking proofs of a former glacial climate have been, in later years, adduced by Dr. Nathorst, who has, from débris in the lacustrine deposits, found that a vegetation identical with that now prevailing in Spitzbergen (Dryas octopetala, Salix polaris, etc.) once lived not only in the lowlands of Southern Sweden but also in Denmark. This being the case, it cannot be doubted that a climate cold enough to produce a continental ice-sheet once prevailed so far south as in Southern Sweden.

That, actnally, Till is formed, and rocks polished and striated by glacier-ice, is so well known from observations in the Alps and elsewhere, that I think Professor Milne himself cannot deny its capability of producing such effects. He points, however, to one circumstance, often observed in connexion with these phenomena, which he thinks not accountable for by the action of glacier-ice, viz. the occurrence of erratic blocks raised to positions above the rock from which they were derived. He explains their occurrence by the "action of coast-ice upon a rising area." If there should be any meaning in this, Professor Milne ought to have called for a sinking area instead of a rising, as, of course, the question must be of the relative height. If a block is attached to floatingice, and the land is rapidly sinking, the block may be deposited in a relatively higher position than that of the parent rock, but not if the land is rising. There are, however, many instances of blocks derived from lower positions, in places where the water never reached. Thus, in Westrogothia blocks of the Cambrian Sandstones are often found reposing on the summits of the Silurian mountains, several hundred feet above their parent rocks, on heights which the sea never reached in post-Tertiary times; and many similar and still more striking instances are recorded from other countries by 
Törnebohm, James Geikie, and other observers. In such cases it is quite impossible to admit floating-ice as the working canse, and we must recur to glacier-ice. It is not here the place to discuss the physical conditions which produce these effects ; it is enough to point to the fact.

If it is thus evident that the phenomena in question can have been effected by the action of a continental ice-sheet, it remains for us to show that they cannot have been effected in the manner advocated by Professor Milne.

That the Till-which in no part of Sweden is more developed than in the south-cannot have been formed by the action of floatingice, is evident to any one who has seen some sections of that deposit, with its striated blocks, heaped confusedly together in the tough tenacious mud. We have, in Sweden, in many places, gravel-beds which have evidently been deposited by shore action, but they have quite another aspect; the gravel is more or less stratified, the stones are rounded, not scratched, and the fine und is washed off, so that this gravel is far less coherent than the Till. The scratches in the rocks are usually best marked below the Till, and it is therefore probable that the result is from the same cause. That they cannot result from the action of coast-ice is evident from many reasons. Firstly, it is impossible to conceive how the scratches conld have such a constant direction in large regions, if they were produced by coast-ice. Professor Milne himself correclly remarks, that the directions of the scratches "point seawards, or else to the lowest land," but, strangely enough, he adds that this circumstance is rather more favourable for his own views. Everybody, however, knows that glacier-ice moves downwards, and therefore it is natural that the scratches, on the whole, have that direction, if produced by glacier-ice. On the contrary, if produced by coast-ice, their direction is independent of the slope of the land, and must vary according to the currents and the winds. Further, in the isles along the Baltic coasts of Sweden, the striation and polishing is most marked on their landward face, from whence the glacier must have come, whereas their outer sides ought to have been more polished and scratched, if the coast-ice had produced these effects.

It cannot be denied that, as Professor Milne says, the abrading action of coast-ice is an undoubted fact, but it must be remarked, that in the coasts of Sweden and Finland, and especially near the route followed by him, this action is excessively small. The rocks are there so hard and compact, and the force of the waves so small, that their action on the rock-surface is hardly perceptible. A rock may be exposed there for hundreds of years to the waves, without the finest scratches being abraded. Professor Milne thinks that, to be preserved, they "must always have remained above sea-level, or else have been shielded by some protective covering during both subsidence and elevation," but it is so far from this being the case that, on the contrary, the scratches are much better preserved beneath the water than in the open air a few feet above it. In the open air the scratches usually become obliterated in a few years by 
the action of the atmospheric agents, and, above all, by the lichens. This is also the reason why the smaller islands and the lower portions of the larger ones, as Professor Milne remarks, are of a whitish colour. As long as the waves hinder the lichens from attaching themselves to the rock, it preserves its scratched and polished surface, but when elevated a few feet above the sea-level, it soon becomes rough and dark. In places that were sheltered from the action of the glacier-ice, the rock is never polished and scratched, though on our coasts these places are usually the most exposed to the action of the waves and to coast-ice.

Geologicai Survex OfFice, STOCKHOLM, November 30 th.

G. Linnarsson.

\section{DEVONIAN GEOLOGY.}

SIR,-One is scarcely surprised to find that the papers of Messrs. H. B. Woodward and C. Reade, in the last October Number of the Geologioar Magazine, afford such strong support to the masterly interpretation of the Geology of Devonshire given to the Geological Society by the late Professor Jukes and published at his own expense.

Professor Jukes's knowledge of the Irish rocks with which he classed those of Devonshire, together with his powerful and practised ability for field observation, entitled his opinions to more consideration than at the time they appeared to receive.

Now that be is gone, it is gratifying to see his 'able outline' being ably filled in with careful details, and should the further revision still bear out his views, this will show how apt was a remark he often made regarding puzzles in field geology, " Put all the evidence down, and it will explain itself."

WrJsIYaN, Nov. $19 i \hbar, 1877$.

\section{Benwyan.}

\section{THE VOLCANIC ROCKS OF SHROPSHIRE.}

Sra,-Mr. S. Allport, in his valuable paper "On Certain Ancient Devitrified Pitchstones and Perlites from the Lower Silurian District of Shropshire" (Quart. Journ. Geol. Soc., vol. xxxiii. part 3, August, 1877, p. 449), read May 23rd, 1877, announced the discovery of the bedded character of the so-called "Greenstone" of the Wrekin. The same fact was communicated by me to the Society on March 21st, 1877. in my paper "On a new area of Upper Cambrian Rocks in South Shropshire," which however did not appear until the publication of part 4 of the Quart. Journ. Geol. Soc., in November, 1877, p. 652. The value of this discovery will be seen when it is remembered that these "Lower Silurian" rocks are really Cambrian, some of them clearly as ancient as the Lingula Flags, if not Menevian, and that they rest upon the bedded volcanic series unconformably. I am working out the details of this great formation, but shall not publish until I have collected further materials.

Weilington, Salop, Dec. $11 t h, 1877$.

Charles Callaway. 